Website. http://hilirisasi.lppm.unand.ac.id

e-ISSN: 2621-7198

\title{
PENERAPAN SISTEM PENANAMAN JAJAR LEGOWO MELALUI PEMBERIAN RHIZOBAKTERI UNTUK PERTUMBUHAN DAN PRODUKSI PADI
}

\author{
Yulmira Yanti ${ }^{1 *}$, Hasmiandy Hamid ${ }^{1}$, Yaherwandi ${ }^{1}$, Noveriza Hermeria ${ }^{2}$ \\ 1) Program Studi Proteksi Tanaman Fakultas Pertanian Universitas Andalas \\ 2) Program Studi Proteksi Tanaman Fakultas Pertanian Universitas Andalas \\ *Email:mira23@gr.unand.ac.id ; yy.anthie79@gmail.com
}

\begin{abstract}
ABSTRAK
Kabupaten Tanah Datar merupakan daerah agraris, lebih $70 \%$ penduduknya bekerja pada sektor pertanian, baik pertanian tanaman pangan, perkebunan, perikanan, maupun peternakan. Nagari Gunung Rajo merupakan salah satu nagari di Kecamatan Batipuh dengan pertanian sebagai sektor ekonomi utama yaitu tanaman padi sawah. Masalah yang sering dihadapi petani Gunung Rajo adalah masalah hama dan penyakit yang menyerang tanaman. Salah satu komponen utama dari program PHT adalah pengendalian hayati dengan memanfaatkan agen hayati rizobakteri indigenus. Aplikasi rizobakteri sangat menguntungkan bagi tanaman karena dapat mempengaruhi pertumbuhan tanaman secara langsung dan tidak langsung. Tujuan kegiatan pemberdayaan kelompok tani ini adalah untuk menambah pengetahuan masyarakat mengenai pemanfaatan rizobakteri yang dapat meningkatkan pertumbuhan dan hasil produksi tanaman padi dengan sistem tanam jajar legowo. Metode yang digunakan dalam kegiatan ini yaitu dengan pelatihan terstruktur dan praktik langsung dilapangan pengaruh rizobakteri terhadap pertumbuhan dan produksi tanaman padi menggunakan sistem jajar legowo. Hasil yang diperoleh dari kegiatan ini yaitu produksi bobot gabah/rumpun tanaman yang diberi perlakuan rizobakteri lebih tinggi sebanyak 40,74 gram dibandingkan dengan tanaman yang tidak diberi perlakuan rizobakteri (tanaman kontrol). Kesimpulan dari kegiatan ini yaitu pertumbuhan dan hasil produksi tanaman yang di aplikasikan menggunakan rizobakteri lebih tinggi dari pada tanaman yang tidak diberi perlakuan rizobakteri. Penggunaan rizobakteri sangat disarankan karena selain mudah untuk didapatkan juga memberikan nilai positif terhadap pertumbuhan tanaman dan baik untuk teknologi lingkungan sekitar tanaman budidaya.
\end{abstract}

Kata Kunci: penerapan, agen hayati, rizobakteri, jajar legowo

\section{Application of Legowo Line Planting System through Rhizobacteria for Growth and Rice Production}

\begin{abstract}
Tanah Datar Regency is an agricultural area of more than $70 \%$ of the population works in the agricultural sector, both food crops, plantations, fisheries, and livestock. Nagari Gunung Rajo which is one of the villages in Batipuh District, with agriculture as the main economic sector of the rice fields. The problems often confronting the farmer on Mount is that of pests and diseases attacking plants. One of the primary components of the PHT program is biological control by utilization of the biological agent for indigenous rhizobacteria. His application of rhizobacteria is a boon to plants because it can affect plant growth directly and indirectly. The purpose of this farm group's empowerment activity is to increase public knowledge of the use of rhizobacteria that can enhance the growth and production of rice plants with the legowo growing system. The method used in this activity is consistent with structured training and direct practice on the issue of rhizobacteria impact on growth and production of rice plants using the legowo growing system. The results from this activity is the production of grain weight/plants support, which was treated by rhizobacteria with an increase of 40.74 grams, compared with the plants that were not treated with the rizobacteria (plant control). The conclusion of this activity is that of growth and the application of the plant production of gifts is higher than that of plants not treated by rizobacteria. This is recommended because it is not only easy to acquire but also good for the growth of plants and for the environmental technology surrounding crops.
\end{abstract}

Keywords: application, biological agents, rhizobacteria, jajar legowo 


\section{PENDAHULUAN}

Kabupaten Tanah Datar merupakan daerah agraris, lebih 70\% penduduknya bekerja pada sektor pertanian, baik pertanian tanaman pangan, perkebunan, perikanan, maupun peternakan. Kelompok tani Ngungun jorong Gantiang Utara merupakan salah satu kelompok tani yang hanya membudidayakan tanaman utama padi sawah (Yanti, et al, 2019). Padi merupakan salah satu tanaman pangan yang memiliki peranan penting sebagai sumber makanan pokok sebagian besar penduduk Indonesia. Semakin bertambahnya jumlah penduduk dari waktu ke waktu menyebabkan kebutuhan makanan pokok seperti beras ikut mengalami peningkatan. Ketahanan, kemandirian dan kedaulatan pangan Indonesia dinilai belum kokoh. Hal ini diindikasikan oleh tingginya impor produk pangan. Hingga tahun 2013 masalah ketahanan pangan khususnya beras menjadi persoalan besar bangsa Indonesia (Pujiasmanto, 2013).

Beras merupakan komoditas strategis yang berperan penting dalam perekonomian dan ketahanan pangan nasional, dan menjadi basis utama dalam revitalisiasi pertanian ke depan. Pemerintah berkeinginan mempertahankan swasembada beras secara berkelanjutan. Peningkatan produktivitas padi $1,5 \%$ per tahun dengan indeks panen 1,52 diperkirakan dapat mempertahankan swasembada beras hingga tahun 2025.

Masalah yang sering dihadapi petani Gunung Rajo adalah masalah hama dan penyakit yang menjadi penyebab pertumbuhan dan hasil produksi dari tanaman padi sawah tersebut. Sesuai dengan program pertanian berkelanjutan yang diterapkan di Indonesia maka teknik pengendalian Organisme Pengganggu Tumbuhan (OPT) pada tanaman palawija harus mengacu pada Pengendalian Hama dan Hama dan penyakit secara Terpadu (PHT). Salah satu komponen utama dari program PHT adalah pengendalian hayati dengan memanfaatkan agensia pengendalian hayati rizobakteri indigenus. Aplikasi rizobakteri sangat menguntungkan bagi tanaman karena selain memacu terbentuknya fitohormon juga berperan dalam menginduksi ketahanan tanaman terhadap patogen. Rizobakteri mempengaruhi pertumbuhan tanaman dalam dua cara yang berbeda, yaitu secara langsung dan tidak langsung. Secara langsung rizobakteri menyediakan tanaman dengan senyawa yang disintesis langsung oleh bakteri, misalnya fitohormon atau memfasilitasi penyerapan nutrisi tertentu dari lingkungan (Glick 1995). Pengaruh secara tidak langsung atau ketahanan terimbas sebagai pengaruh induksi ketahanan dicirikan dengan adanya akumulasi asam salisilat dan pathogenesis related protein (PR-protein) (Chen et al. 2000).

Keuntungan penggunaan agensia hayati indigenus antara lain: ramah lingkungan, berkesinambungan, kesesuaien ekologis, dan dapat diintegrasikan dalam program PHT serta dapat diperbanyak dengan teknologi yang sederhana dan mudah cara aplikasinya. Penerapan PHT dengan menggunakan limbah dan rizobakteri telah mendapatkan banyak keberhasilan diantaranya di Nagari Salimpat, di Nagari Aie Dingin dan di Nagari Sungai Durian. Penggunaan rizobakteri dan rizokompos pada budidaya tanaman bawang merah di nagari Gunung Rajo memberikan hasil pertumbuhan yang sangat baik dibandingkan dengan kontrol. Rizobakteri berperan sebagai agens hayati dalam pengendallian OPT serta juga sebagai biofertilizer pada tanaman karena dapat memacu pertumbuhan dan perkembangan tanaman bawah merah di lapangan (Yanti et al, 2019). 
Website. http://hilirisasi.lppm.unand.ac.id e-ISSN: 2621-7198

Selain penggunaan agen hayati sistem atau cara penanaman juga berpengaruh terhadap hasil produksi terhadap tanaman yang dibudidayakan. Penggunaan teknologi sistem tanam dalam budidaya padi diharapkan dapat mempengaruhi hasil produksi, dan pada akhirnya akan mempengaruhi pendapatan petani pangan. Yoshie dan Rita (2010) menyatakan, teknologi budidaya yang tepat tidak hanya menyangkut masalah penggunaan varietas unggul, tetapi juga pemilihan metode tanam yang tepat. Salah satu teknologi yang dapat diterapkan sebagai upaya peningkatan produksi padi adalah dengan metode tanam jajar legowo. Prinsip dari sistem tanam jajar legowo adalah meningkatkan populasi tanaman dengan mengatur jarak tanam sehingga pertanaman akan memiliki barisan tanaman yang diselingi oleh barisan kosong dimana jarak tanam pada barisan pinggir setengah kali jarak tanam antar barisan. Sistem tanam jajar legowo merupakan salah satu rekomendasi yang terdapat dalam paket anjuran Pengelolaan Tanaman Terpadu (PTT).

Adapun tujuan kegiatan ini adalah untuk menambah pengetahuan masyarakat mengenai pemanfaatan rizobakteri yang dapat meningkatkan pertumbuhan dan hasil produksi tanaman padi dengan sistem jajar legowo. Dengan demikian diharapkan masyarakat dapat memanfaatkan pengetahuan dan keterampilan yang telah diberikan untuk diterapkan dalam penanaman padi sawah selanjutnya sehingga hasil produksi padi juga meningkat.

\section{METODOLOGI}

Program ini dilaksanakan dari bulan Maret hingga Juni 2020 di lokasi Kelompok Tani Ngungun Nagari Gunung Rajo Kabupaten Tanah Datar Sumatera Barat dengan metode penyuluhan dan demonstrasi. Peserta kegiatan ini ialah Tim Unand, mahasiswa Fakultas Pertanian, Kelompok Tani Ngungun serta masyarakat Nagari Gunung Rajo. Kegiatan penyuluhan dilakukan dengan pemberian materi olh narasumber dan dilanjutkan dengan diskusi perihal penerapan penanaman padi dengan sistem jajar legowo yang menggunakan aplikasi rizobakteri. Sedangkan kegiatan demonstrasi dilakukan setelah penyuluhan selesai diberikan, sehingga masyarakat menjadi lebih paham mengenai bagaimana proses pelaksanaannya. Demonstrasi tersebut langsung dibantu oleh mahasiswa Fakultas Pertanian dan kelompok tani Sawah Ngungun.

\section{A. Survey Pendahuluan dan Pendekatan Sosial}

Tahap ini bertujuan untuk melakukan komunikasi dan sosialisasi maksud dan tujuan kegiatan program penelitian melalui ketua kelompok tani serta masyarakat lainnya. Dari kegiatan ini diharapkan terciptanya suatu kerja sama antara masyarakat, unit pengelola penyuluhan berbasis petani dan aparat pemerintah.

Selain itu, kegiatan ini akan memperoleh legitimasi bagi semua kegiatan yang berkaitan dengan pelaksanaan penelitian, sehingga dukungan semua pihak dapat diperoleh. Masyarakat bersedia untuk mengikuti kegiatan ini serta menyediakan waktu dan lahan percontohan. 
Website. http://hilirisasi.lppm.unand.ac.id e-ISSN: 2621-7198

\section{B. Penyuluhan dan Diskusi}

Tim pelaksana kegiatan dengan aparat desa, tokoh masyarakat, dan para petani berkumpul di Kantor Wali Nagari serta kelompok tani Ngungun yang lahan sawahnya akan digunakan sebagai demplot. Kegiatan ini bertujuan untuk memberikan materi penyuluhan serta diskusi berupa:

a. Hama dan penyakit yang sering menyerang tanaman padi

b. Budidaya tanaman padi dengan penerapan sistem tanam jajar legowo dan penerapan PHT biointensive

c. Teknik perbanyakan dan penggunaan agen hayati rizobakteri dan mikroorganisme lokal.

\section{Pelatihan dan Demonstrasi}

Pelatihan yang dilaksakan bertujuan untuk menambah wawasan dan pengetahuan petani tentang peran dan manfaat rizobakteri bagi tanaman padi yang dapat meningkatkan pertumbuhan tanaman dan juga dapat meningkatkan hasil produktivitas dari tanaman yang diusahakan, serta membantu petani untuk dapat mengubah pola penanaman dari biasanya menjadi sistem tanam jajar legowo yang dapa meminimalisir munculnya hama dan penyakit karena jarak tanam yang lebih beraturan. Pelatihan ini dilakukan pada semua anggota kelompok tani mitra.

Demonstrasi dilakukan setelah kegiatan penyuluhan. Untuk lebih meyakinkan petani padi tentang kemampuan rizobakteri, maka dibuat demplot percontohan penanaman padi dengan sistem jajar legowo dengan menggunakan aplikasi rizobakteri di salah satu lahan milik anggota kelompok tani. Demplot penanaman padi dengan jarak tanam pada sistem jajar legowo (4:1) adalah $20 \mathrm{~cm}$ (antar barisan dan pada barisan tengah) X $10 \mathrm{~cm}$ (barisan pinggir) X $40 \mathrm{~cm}$ (barisan kosong).

\section{HASIL DAN PEMBAHASAN}

\section{A. Survey Pendahuluan dan Pendekatan Sosial}

Sebelum melaksanakan kegiatan, tim melakukan survey dengan mengunjungi lokasi dan melakukan wawancara bersama wali nagari (Gambar 1). Diskusi mengenai permasalahan budidaya tanaman dilakukan sebagai bahan pertimbangan untuk melakukan kegiatan.

Kelompok tani mitra di Nagari Gunung Rajo merupakan kelompok tani yang mengusahakan budidaya padi sawah. Dalam pelaksanaan budidaya petani tidak melakukan pergiliran tanaman dalam mengolah lahan pertanian. 

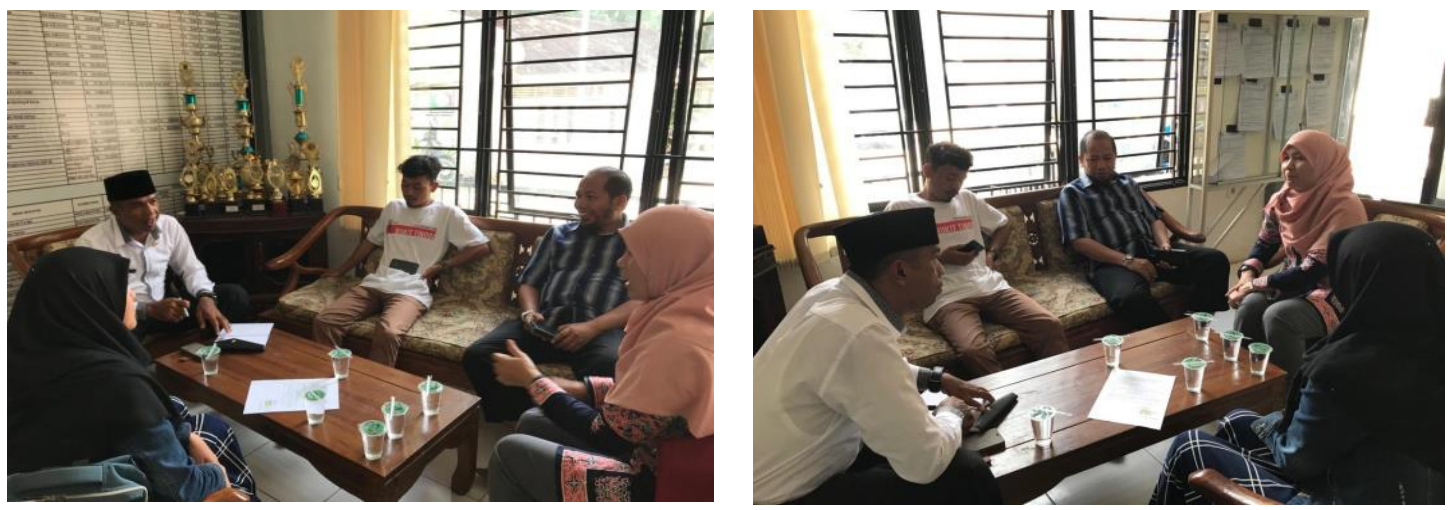

Gambar 1. Survei Pendahuluan di Kantor Wali Nagari Bersama Bapak Wali Nagari Gunung Rajo

\section{B. Penyuluhan dan diskusi}

Penyuluhan dilakukan di Gedung Balai Serbaguna Nagari Gunung Rajo dengan melibatkan aparat pemerintahan Nagari, kelompok tani Ngungun dan masyarakat setempat. (Gambar 2). Adapun materi yang diberikan ialah: (1) Hama dan penyakit yang sering menyerang tanaman padi; (2) Budidaya tanaman padi dengan penerapan sistem tanam jajar legowo; dan (3) Pemanfaatan rizobakteri sebagai agen hayati ramah lingkungan yang dapat meningkatkan pertumbuhan dan juga hasil produksi tanaman padi.

Hasil yang diperoleh dari kegiatan ini yaitu masyarakat mempunyai pemahaman baru mengenai cara budidaya tanaman padi dengan sistem jajar legowo serta pemanfaatan rizobakteri yang dapat meningkatkan pertumbuhan tanaman padi serta hasil produksi tanaman itu sendiri.

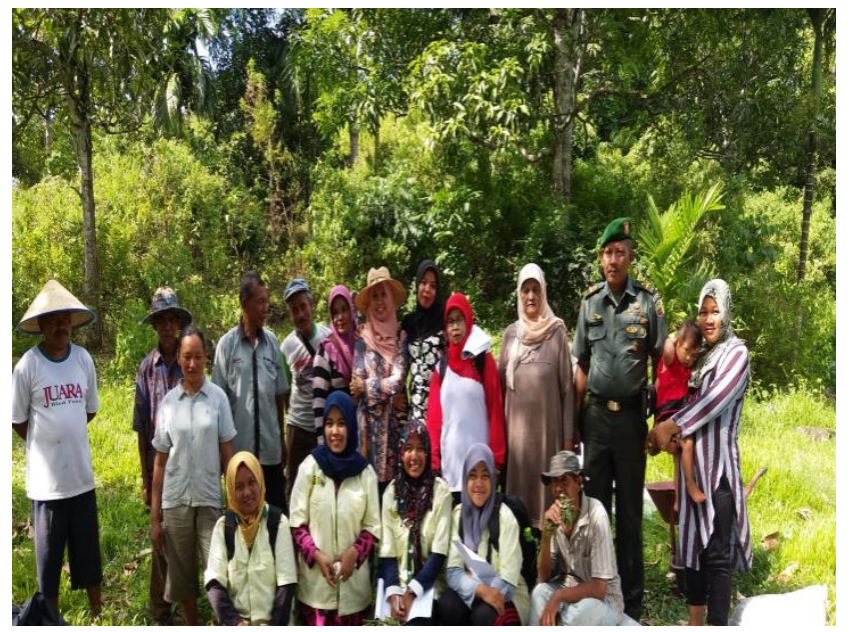

Gambar 2. Kegiatan Penyuluhan Bersama Kelompok Tani dan Aparat Nagari

\section{Pelatihan dan Demonstrasi}

Pada kegiatan ini, petani diberi pelatihan untuk memanfaatkan agens hayati rizobakteri dalam teknik budidaya padi sawah yang menggunakan sistem tanam jajar legowo. Petani juga diberikan pengetahuan terkait keunggulan dalam penggunaan 
agens hayati. Pentingnya peran agens hayati dalam mengendalikan hama dan penyakit tanaman padi juga disampaikan kepada kelompok tani. Untuk mempersiapkan agens hayati, petani cukup diberikan sosialisasi dan simulasi pembuatannya di tahap laboratorium.

Selain itu, petani juga diberikan pemahaman cara-cara penerapan penanaman padi dengan sistem jajar legowo yang lebih baik dari cara tanam padi biasanya. Tipe sistem tanam jajar legowo ini dipilih sebagai anjuran kepada petani untuk diterapkan dalam rangka peningkatan produksi padi karena berdasarkan hasil penelitian yang telah dilakukan dengan melihat serta mempertimbangkan tingkat efisiensi dan efektivitas biaya produksi dalam penggunaan pupuk dan benih serta pengaruhnya terhadap hasil produksi tanaman padi.
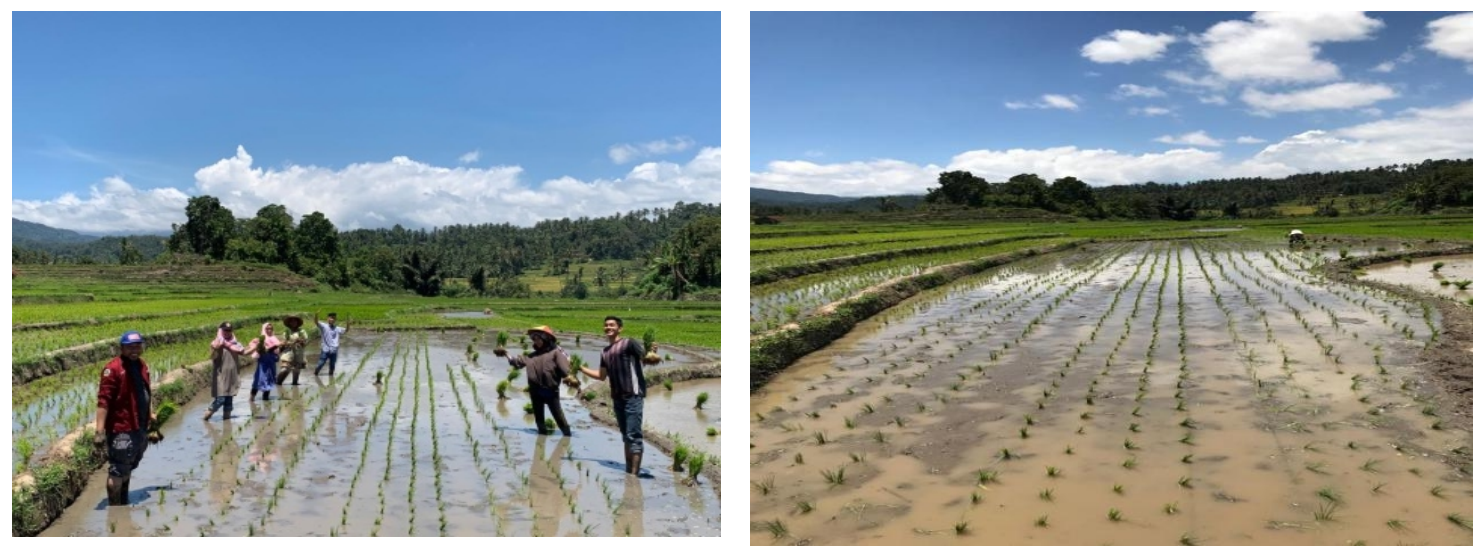

Gambar 3. Demonstrasi Langsung Penanaman Padi dengan Sistem Jajar Legowo

Kegiatan penerapan metode tanam jajar legowo ini dilakukan oleh tim Fakultas Pertanian Universitas Andalas dengan kelompok tani mitra yaitu Kelompok Tani Ngungun menggunakan metode sosialisasi dan demonstrasi langsung dilapangan yang dihadiri oleh kelompok tani Ngungun dan masyarakat setempat.

Metode penanaman yang diterapkan yaitu sistem tanam jajar legowo dengan perbandingan (4:1). Selanjutnya sebelum gabah disemai, gabah padi terlebih dahulu direndam menggunakan rizobakteri selama 10 menit kemudian baru disemai sampai umur benih berkisar 20-25 hari. Selanjutnya saat pemindahan ke lapangan atau ke petakan sawah untuk ditanam, akar benih direndam kembali menggunakan rizobakteri. Setelah direndam selama lebih kurang 10 menit, padi ditanam dengan cara menanam dimana setiap empat baris tanaman diselingi oleh satu barisan kosong yang memiliki jarak dua kali dari jarak tanaman antar barisan.

Dengan sistem legowo seperti ini maka setiap baris tanaman ke-1 dan ke-4 akan menjadi tanaman pinggir yang diharapkan dapat diperoleh hasil tinggi dari adanya efek tanaman pinggir. Dengan demikian jarak tanam pada sistem jajar legowo $(4: 1)$ adalah $20 \mathrm{~cm}$ (antar barisan dan pada barisan tengah) X $10 \mathrm{~cm}$ (barisan pinggir) X 40 cm (barisan kosong) (Gambar 3). 

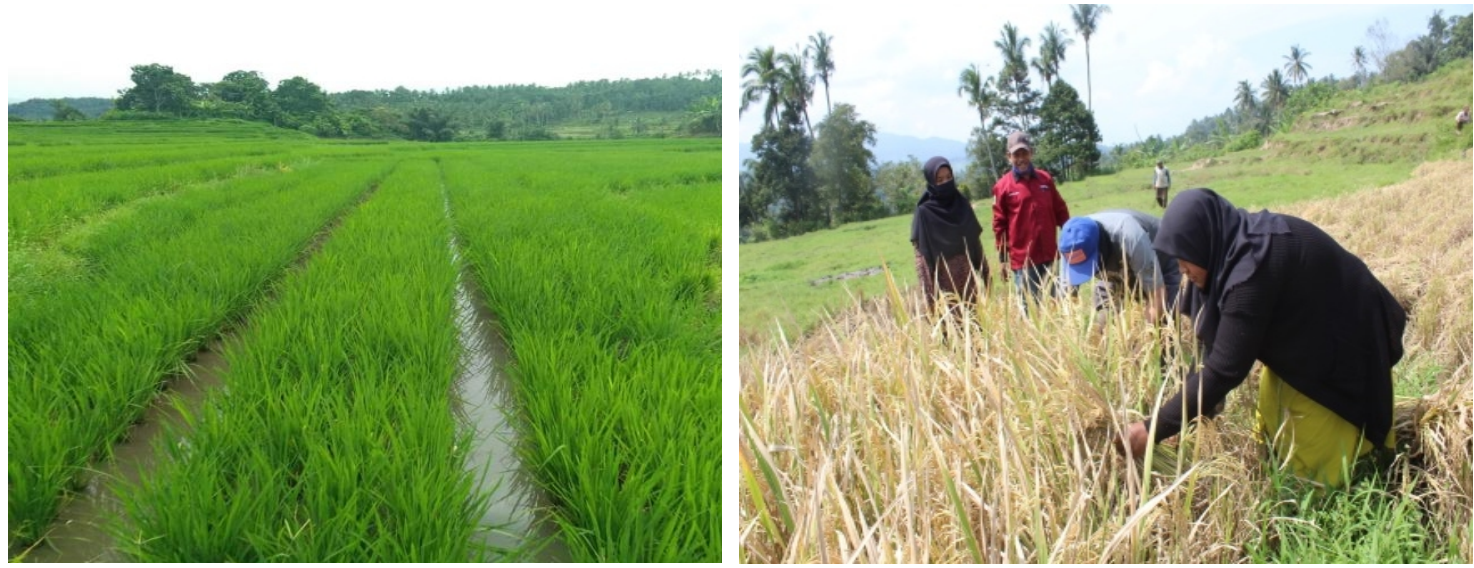

Gambar 4. Pertumbuhan Tanaman Padi dan Proses Pemanenan

Tabel 1. Tinggi Tanaman Padi (cm) Umur 14 28, 42 dan 56 HST

\begin{tabular}{ccccc}
\hline \multirow{2}{*}{ Perlakuan } & \multicolumn{4}{c}{ Tinggi Tanaman (HST) } \\
\cline { 2 - 5 } & 14 & 28 & 42 & 56 \\
\hline Rizobakteri & $39 \mathrm{~cm}$ & $50 \mathrm{~cm}$ & $62 \mathrm{~cm}$ & $65 \mathrm{~cm}$ \\
Kontrol & $13 \mathrm{~cm}$ & $30 \mathrm{~cm}$ & $43 \mathrm{~cm}$ & $52 \mathrm{~cm}$ \\
\hline
\end{tabular}

Dari Tabel 1. pengamatan mulai dari umur 14 hari setelah tanam hingga umur 56 hari setelah tanam dapat dilihat bahwa tinggi tanaman padi yang diberi perlakuan rizobakteri memiliki pertumbuhan lebih cepat disbanding dengan perlakuan kontrol.

Tabel 2. Jumlah Anakan Padi Umur 14 28, 42 dan 56 HST

\begin{tabular}{ccccc}
\hline \multirow{2}{*}{ Perlakuan } & \multicolumn{4}{c}{ Jumlah Anakan (HST) } \\
\cline { 2 - 5 } & 14 & 28 & 42 & 56 \\
\hline Rizobakteri & 9 & 18 & 28 & 30 \\
Kontrol & 6 & 8 & 16 & 21 \\
\hline
\end{tabular}

Sedangkan untuk respon anakan tanaman padi yang diberi perlakuan dengan rizobakteri memiliki jumlah anakan yang lebih banyak dibandingkan dengan tanaman yang tidak diberi perlakuan (kontrol). Untuk tanaman padi yang diberi rizobakteri memiliki anakan sebanyak 30 pada pengamatan ke empat (pengamatan 56 hari setelah tanam), sementara yang tidak diberi rizobakteri hanya memiliki anakan sebanyak 21 (pada pengamatan yang sama) seperti pada gambar 4

Pemanenan padi biasanya bisa dilakukan setelah malai berumur 30-35 hari setelah berbunga merata dan $90-95 \%$ gabah dari malai sudah tampak menguning. Panen dilakukan dengan cara tradisional yaitu menggunakan sabit. Sabit yang digunakan adalah sabit dalam keadaan tajam sehingga memudahkan dalam memotong atau membabat pangkal batang padi yang sudah matang. Setelah batang padi selesai dibabat, padi tersebut disusun menggunung untuk selanjutnya dilakukan pemisahan bulir padi dari tangkainya dengan cara merontokkannya menggunakan papan gebyok 
Website. http://hilirisasi.lppm.unand.ac.id e-ISSN: 2621-7198

yang terbuat dari kayu. Prosesnya dengan cara manual yaitu dengan menghempaskan batang padi pada papan kayu, kemudian bulir padi tersebut dikumpulkan dan dimasukkan ke dalam karung yang telah disediakan.

Tabel 3. Bobot Gabah/Rumpun

\begin{tabular}{lc}
\hline Perlakuan & Bobot Gabah (gram) \\
\hline Rizobakteri & 77.94 \\
Kontrol & 37.20
\end{tabular}

Dari Tabel 3 dapat dilihat juga perbandingan hasil yang diperoleh di lapangan dari bobot gabah/rumpun nya yaitu bobot gabah yang diberi perlakuan dengan rizobakteri ini memiliki bobot yang lebih tinggi dibandingkan dengan perlakuan kontrol. Penggunaan system tanam dengan jarak yang lebih tepat juga memberikan dampak yang baik terhadap pertumbuhan dan hasil produksi dari tanaman padi.

\section{KESIMPULAN DAN SARAN}

Kegiatan ini sangat bermanfaat bagi masyarakat khususnya kelompok tani Ngungun jorong Gantiang Utara. Antusias dan partisipasi aktif dari masyarakat sangat menunjang keberhasilan dari kegiatan ini. Pertumbuhan dan hasil produksi tanaman yang di aplikasikan menggunakan rizobakteri lebih tinggi dari pada tanaman yang tidak diberi perlakuan rizobakteri. Untuk tinggi tanaman dari pengamatan umur tanaman 14 hari setelah tanam hingga umur 56 hari sangat terlihat perbedaannya begitu juga dengan jumlah anakan dengan waktu pengamatan yang sama. Sementara untuk jumlah bobot gabah/rumpun sangat terlihat perbandingan yang signifikan dari hasilnya yaitu perlakuan rizobakteri memiliki bobot gabah/rumpunnya sebanyak 77.94 (gr) sementara untuk kontrol hanya diperoleh sebanyak 37.20 (gr).

Penggunaan rizobakteri sangat disarankan karena selain mudah untuk didapatkan juga memberikan nilai positif terhadap pertumbuhan tanaman dan baik untuk teknologi lingkungan sekitar tanaman budidaya. Sistem tanam padi dengan jajar legowo ini juga sangat dianjurkan diterapkan oleh petani untuk mengurangi resiko terserang hama juga untuk mempertimbangkan tingkat efisiensi dan efektivitas biaya produksi dalam penggunaan pupuk dan benih serta pengaruhnya terhadap hasil produksi tanaman padi.

\section{UCAPAN TERIMAKASIH}

Penulis mengucapkan terima kasih kepada Direktorat Riset dan Pengabdian Masyarakat Deputi Bidang Penguatan Riset dan Pengembangan Kementerian Riset dan Teknologi/Badan Riset dan Inovasi Nasional dengan Kontrak Penelitian Nomor: 034/SP2H/LT/DRPM/2020. Sehingga berjalan dengan baik Pengabdian di Kelompok Tani. 


\section{DAFTAR PUSTAKA}

Badan Litbang. 2009. Pedoman Umum PTT Padi Sawah. Badan Penelitian dan Pengembangan Pertanian, Departemen Pertanian. $20 \mathrm{hlm}$.

Chen, C, Belanger RR., Benhamou N \& Paulitz TC, 2000, Defense enzymes induced in cucumber roots by treatment with plant growth-promoting rhizobacteria (PGPR) and Pythium aphanidermantum. Physiol. Mol. Plant. Pathol. 56: 13-23.

Glick, B.R. 1995. The enhancement of plant growth by free-living bacteria. Can. J. Microbiol. 4: 109-117.

Pujiasmanto, 2013. Perkuat ketahanan pangan nasional kita. Guru Besar Fakultas Pertanian Universitas Sebelas Maret (UNS). Surakarta. http://www.uns.ac.id

Yanti, Y., Hamid, H., Habazar, T., Reflin., Nurbailis., Yaherwandi., Nilisma, M., Diandinny, A. 2019. Peningkatan Produksi Bawang Merah Melalui Aplikasi Yuyaost dan Trichoderma di Kelompok Tani Ngungun Jorong Gantiang Utara. Jurnal Hilirisasi IPTEKS. Vol. 2 No. 4a. Hal. 333-342

Yanti, Y., Hamid, H., Santoso, P. 2019. Pemberdayaan Masyarakat Melalui Pemanfaatan Limbah Organik Pada Budidaya Bawang Merah di Nagari Gunung Rajo. Jurnal Hilirisasi IPTEKS. Vol. 2 No. 3a. Hal. 149-158

Yoshie dan Rita, M. 2010. Perbandingan Pendapatan Usahatani Padi (Oryza sativa L.) Sawah Sistem Tanam Pindah dan Tanam Benih Langsung di Desa Sidomulyo Kecamatan Anggana Kabupaten Kutai Kartanegara. 7(2):30-36. 